\title{
Experimental and modeling geochemical study of sandstones in the Pannonian Basin (Central Europe) for potential underground hydrogen storage
}

ORSOLYA GELENCSÉR ${ }^{1,2}$, ZSUZSANNA SZABÓKRAUSZ $^{2}$, LÁSZLÓ TAMÁS MIKA ${ }^{3}$, DANIEL BREITNER ${ }^{1}$, TIBOR NÉMETH ${ }^{2}$, CSABA SZABÓ $^{2}$ AND GYÖRGY FALUS $^{4}$

${ }^{1}$ O\&GD Central Ltd.

${ }^{2}$ Eötvös University

${ }^{3}$ Budapest University of Technology and Economics

${ }^{4}$ Mining and Geological Survey of Hungary

Presenting Author: di.go.kgy@gmail.com

One of the most common and safest ways of large scale and long-term (several months) storage of hydrogen $\left(\mathrm{H}_{2}\right)$ is in depleted gas fields. In spite of the safe conditions, undesirable reactions producing gases, such as $\mathrm{H}_{2} \mathrm{~S}$ and $\mathrm{CH}_{4}$, and mineral precipitation/dissolution are possible, which may result in the loss of $\mathrm{H}_{2}$.

The objective of our modeling and experimental study is to investigate the rate and extent of $\mathrm{H}_{2}$ induced redox reactions which can occur during underground $\mathrm{H}_{2}$ storage (UHS). Cores, cuttings and pore water samples were collected from a typical Late Miocene-Pliocene sandstone reservoir in the Pannonian Basin. Using detailed petrography and X-ray diffraction data, geochemical models were built to estimate the rate of dissolution of primary minerals.

Two types of models are built: 1/ equilibrium simulations, where the geochemical reactions are considered to be instantaneous and $2 /$ kinetic batch models where interactions among $\mathrm{H}_{2}$, fluid and minerals are studied in time.

Static batch experiments (composed by single or more mineral phases, fluid, and $\mathrm{H}_{2}$ ) are still running which will be comparable with the simulations. These experiments are performed at temperature $\left(100-150^{\circ} \mathrm{C}\right)$ and pressure range of the studied formation, expected for UHS.

Petrography of the sandstones shows that beside quartz, the rock consists of potentially redox sensitive minerals such as calcite, dolomite, detrital and authigenic clay minerals and $1 \mathrm{w} \%$ sulfide.

The first modeling results show that $\mathrm{H}_{2}$ has an impact on sulfides even at higher temperature and pressure, but no significant effect was found on the carbonate phases (calcite, dolomite). 